\title{
Erratum to: Identification of a soybean chloroplast DNA replication origin-binding protein
}

\author{
Matthew G. Lassen · Sunita Kochhar •
}

Brent L. Nielsen

Published online: 16 February 2011

(C) Springer Science+Business Media B.V. 2011

Erratum to: Plant Mol Biol

DOI 10.1007/s11103-011-9736-6

Due to an unfortunate turn of events, the second author's name appeared incorrectly in the original publication. The correct representation of the authors and their affiliations are listed above and below and should be treated as definitive by the reader.

The online version of the original article can be found under doi:10.1007/s11103-011-9736-6.

M. G. Lassen · S. Kochhar · B. L. Nielsen $(\bowtie)$

Department of Microbiology and Molecular Biology,

Brigham Young University, 775 WIDB, Provo,

UT 84602, USA

e-mail: brentnielsen@byu.edu

M. G. Lassen

Center for Advanced Drug Research, SRI International,

Harrisonburg, VI 22802, USA

S. Kochhar

National Botanical Research Institute, Lucknow 226001, India 